\title{
Scholarship and the research environment
}

'Teaching is the highest form of understanding.' (Aristotle; 384 - 322 BC)

I recently attended a two-day course entitled 'Postgraduate supervision in Health Sciences' and was intrigued by the considerable number of clinical staff who were involved in demanding doctoral degree research, supervising Honours and Masters degree students.

The new exit requirements from the Health Professions Council of South Africa (HPCSA), alluded to in a previous editorial, place additional demands on radiologists in university-affiliated hospitals functioning in resource-limited environments. Despite an additional limited commodity (the research supervisor), original work is consistently produced and submitted to the $S A J R$, and other international journals, for consideration; this is a reflection of the practitioners' dedication to scholarship.

The American educator, Ernest Leroy Boyer (1928 - 1995), President of the Carnegie Foundation for the Advancement of Teaching, classified four types of scholarship (viz. discovery, integration, application and teaching) in his report Scholarship Reconsidered: Priorities of the Professoriate. ${ }^{[1]}$ The four domains of scholarship proposed by Boyer described how the separate functions created a dynamic whole.

The identification of teaching as scholarship allowed teaching to receive institutional recognition and gave rise to the Scholarship of Teaching, or Scholarship of Teaching and Learning (SoTL), ${ }^{[2]}$ as an essential activity in universities. Although teaching today may at times be considered routine and yet another inconvenient duty, when defined as scholarship, teaching both 'educates and entices future scholars. ${ }^{[1]}$ It is this opportunity that is afforded to academics involved in supervising Masters degree students. The supervisor must be well-informed. At times, the process of guiding a student may seem a selfless endeavour, but it also allows a supervisor to gain knowledge and take pride in the student's success.

\section{SAJR editorial board}

I am delighted to welcome Dr Farhana Suleman to the editorial board, which operates to assist the editor in the manuscript adjudication and editing processes. Dr Suleman is a fulltime radiologist at Steve Biko Hospital. Her willingness to be involved reflects her dedication to scholarship and the radiological literature.

\section{Razaan Davis \\ Editor}

1. Boyer EL. Scholarship Reconsidered: Priorities of the Professoriate. New York: The Carnegie Foundation for the Advancement of Teaching, 1997.

2. Hill PAL. Twenty Years On: Ernest Boyer, Scholarship and the Scholarship of Teaching. http://www. teaching-learning.utas.edu.au (accessed 25 April 2013).

S Afr J Rad 2013;17(2):50. DOI:10.7196/SAJR.884

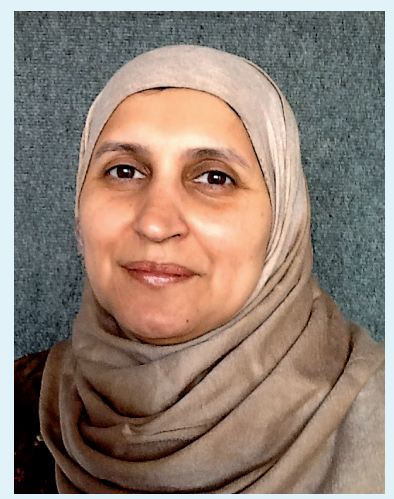

\section{Dr Farhana Suleman}

Dr Farhana Suleman, MB ChB, FCRad (D) (SA), MMedRad (D), did her internship in 1990 at Ga-Rankuwa Hospital. After some years in general practice, she moved to 1 Military Hospital as Principal Medical Officer in the General Radiology Department, subsequently to Dr George Mukhari Hospital's Department of Diagnostic Radiology, and in May 2012 was appointed Head of Clinical Unit in Radiology at Steve Biko Academic Hospital and the University of Pretoria. She has contributed to the literature, with several articles authored and co-authored, and published locally and internationally, in inter alia Pediatric Surgery International, South African Journal of Radiology, South African Orthopaedic Journal, and Spine Journal. 